\title{
Aplikasi Media Pembelajaran Matematika Kelas VII SMP Gunungjati 2 Purwokerto
}

\author{
(Mathematics Learning Media Application Grade VII \\ SMP Gunungjati 2 Purwokerto)
}

\author{
Lahan adi Purwanto ${ }^{1}$, Dimas Reynaldi Yoga Pamungkas ${ }^{2}$ \\ Teknik Informatika-Universitas Muhammadiyah Purwokerto \\ ${ }^{1}$ lahanadipurwanto@ump.ac.id
}

\begin{abstract}
ABSTRAK
SMP Gunungjati 2 Purwokerto merupakan salah satu Sekolah Menengah Pertama yang berada di Kecamatan Purwokerto Barat, Kabupaten Banyumas. Selama ini masih menggunakan sistem pembelajaran secara semi konvensional atau dengan cara biasa, sudah menggunakan alat bantu media pembelajaran tetapi sangat jarang digunakan. Aplikasi yang dibangun ini merupakan sebuah alat bantu dalam kegiatan proses pembelajaran di kelas terutama pada Matematika. Media pembelajaran ini dapat membantu guru dalam menyampaikan materi pelajaran dengan mudah dan dapat meningkatkan semangat belajar serta motivasi belajar siswa agar prestasi yang diraih menjadi lebih maksimal. Aplikasi ini dibuat menggunakan software Adobe Flash Professional CS6. Metode pengembangan sistem yang digunakan yaitu metode Multimedia Development Life Cycle (MDLC) dengan enam tahapan yaitu: konsep, perancangan, pengumpulan bahan, pembuatan, pengujian, dan distribusi.
\end{abstract}

Kata kunci: Media Pembelajaran, Matematika, Adobe Flash CS6.

\begin{abstract}
SMP Gunungjati 2 Purwokerto is one of the Junior High Schools located in the District of West Purwokerto, Banyumas Regency. All this time still using a semi-conventional learning system or in the usual way, already using learning media tools but very rarely used. This application is a tool for learning activities in the classroom, especially in Mathematics. This learning media can help the teacher to convey the subject matter easily and can increase the enthusiasm for learning and student learning motivation so that the achievement achieved becomes more maximal. This application is made using Adobe Flash Professional CS6 software. The system development method used is the Multimedia Development Life Cycle (MDLC) method with six stages: concept, design, material collection, manufacture, testing, and distribution.
\end{abstract}

Keywords: Learning Media, Mathematics, Adobe Flash CS6.

\section{PENDAHULUAN}

Matematika merupakan salah satu mata pelajaran yang memerlukan ketelitian dalam mempelajarinya. Kurikulum yang digunakan pada SMP Gunungjati 2 Purwokerto adalah kurikulum 2013. Berdasarkan hasil observasi langsung, lebih dari $80 \%$ guru mengajar menggunakan metode konvensional. Berdasarkan wawancara langsung dengan guru matematika SMP Gunungjati 2 Purwokerto, setengah dari jumlah siswa SMP 
Gunungjati 2 Purwokerto menganggap matematika adalah pelajaran yang sulit dimengerti, tidak menyenangkan, membosankan, dan rata-rata nilai UN pada SMP Gunungjati 2 Purwokerto yang terendah yaitu mata pelajaran matematika. Siswa sering merasa kesulitan dalam memahami soal, karena matematika tidak hanya hafalan tetapi butuh penalaran. Oleh karena itu, perlu penyampaian contoh soal serta penjelasannya dan kegiatan yang dipersiapkan hendaknya dilakukan dalam situasi yang lebih menarik dan menyenangkan serta mudah diterima.

Laju perkembangan Ilmu Pengetahuan dan Teknologi (IPTEK) dewasa ini semakin hari semakin pesat perkembangannya. Perkembangan tersebut disebabkan adanya tuntutan dan kebutuhan manusia yang juga semakin berkembang di berbagai bidang (Suhardi dkk., 2013). Perkembangan teknologi juga memiliki pengaruh penting terhadap pendidikan. Misalnya Handphone, Tablet, komputer, dan internet telah mempengaruhi proses pembelajaran sampai saat ini. Aturan-aturan dari pendidik telah berubah karena dipengaruhi media dan teknologi yang digunakan di dalam kelas. Banyak media pembelajaran yang dapat digunakan, salah satunya yaitu Media Pembelajaran pada gadget.

Media pembelajaran adalah segala sesuatu yang dapat digunakan untuk menyalurkan pesan (bahan pembelajaran), sehingga dapat merangsang perhatian, minat, pikiran, dan perasaan siswa dalam kegiatan belajar untuk mencapai tujuan belajar (Daryanto, 2013). Dalam media pembelajaran mampu melatih pengetahuan, keterampilan, dan ketepatan dalam sistem pembelajaran dengan cara yang lebih menarik. Penggunaan media pembelajaran telah membantu guru di SMA Al-Islam 3 Surakarta dalam meningkatkan motivasi belajar peserta didik (Setiawan, 2013). Penggunaan media pembelajaran di SMK Muhammadiyah 3 Surakarta juga telah membantu guru dalam usaha meningkatkan motivasi belajar peserta didik (Juriah, 2014).

Aplikasi pembelajaran Matematika merupakan salah satu pendekatan dalam sistem belajar. Matematika merupakan ilmu pokok yang harus dipelajari semua orang dan mencakup aplikasi yang luas dalam aspek kehidupan. Oleh karena itu, inovasi dalam pembelajaran dan strategi pembelajaran Matematika perlu dilakukan. Sering kali dengan banyaknya jam pelajaran Matematika dibandingkan jam mata pelajaran lain dan banyaknya materi yang ada membuat siswa merasa jenuh, stres, dan bosan dalam belajar Matematika. Ditambah lagi dengan penyampaian guru yang lebih mengacu pada teoriteori Matematika yang banyak dan kompleks. Dengan demikian minat belajar siswa menurun dan mengakibatkan nilai yang kurang memuaskan.

Berdasarkan masalah di atas, salah satu solusi yaitu membuat aplikasi pembelajaran matematika menggunakan software Adobe Flash Professional CS6 pada pokok bahasan segitiga dan segiempat kelas VII SMP 2 Gunungjati Purwokerto. Aplikasi pembelajaran Matematika ini juga memuat soal-soal UN (Ujian Nasional) tahun sebelumnya yang terdapat pada kuis untuk latihan soal. Dengan adanya tampilan aplikasi yang menarik dan tampilan soal yang acak diharapkan dapat meningkatkan kemampuan siswa dan juga nilai siswa, serta merasa lebih tertarik dan tidak akan merasa bosan ataupun stres.

\section{METODE}

Metode pengembangan yang digunakan dalam pengembangan aplikasi ini adalah menggunakan model Multimedia Development Life Cycle (MDLC) seperti ditunjukkan pada Gambar 1 . 


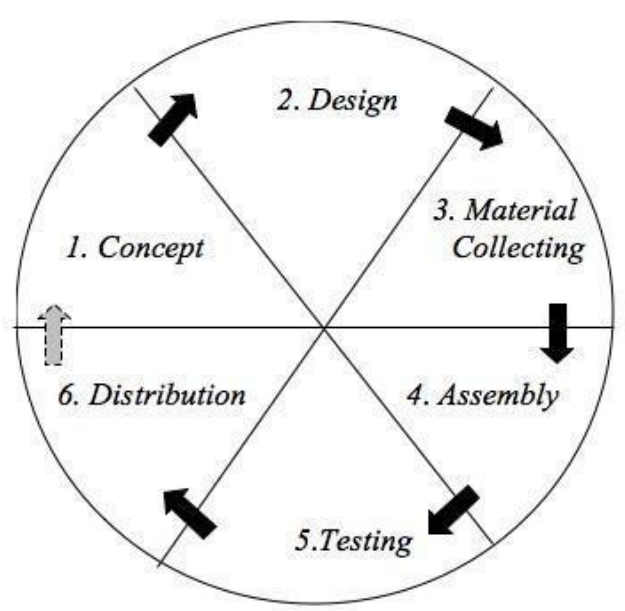

Gambar 1. Multimedia Development Life Cycle (MDLC) (Sutopo, 2003)

\section{Concept (Konsep)}

Tahap konsep merupakan tahap awal dari pengembangan aplikasi media pembelajaran. Kegiatan yang dilakukan dalam tahap konsep meliputi menentukan tujuan pembelajaran, menentukan konsep materi pembelajaran, dan menentukan konsep isi aplikasi pembelajaran.

\section{Design (Desain)}

Tahapan desain di dalamnya mencakup pembuatan desain sistem dan desain User Interface (UI). Hal ini bertujuan agar pembuatan media pembelajaran lebih terarah dan tertata dan pastinya disesuaikan dengan kebutuhan pengguna. Desain sistem media pembelajaran akan dibuat dengan menggunakan Use Case Diagram dan Activity Diagram.

Use Case Diagram merupakan salah satu diagram UML (Unified Modelling Language) yang digunakan untuk menggambarkan abstraksi dari interaksi antara sistem dan user. Use Case bekerja dengan cara mendeskripsikan tipe interaksi antara user sebuah sistem dengan sistemnya melalui sebuah alur yang jelas dalam sistem yang nantinya akan digunakan. Diagram UML lain yang digunakan dalam tahap desain adalah Activity Diagram. Activity Diagram merupakan representasi grafis dari seluruh tahapan alur kerja. Activity Diagram mengandung aktivitas, pilihan tindakan, perulangan, dan hasil dari aktivitas tersebut. Pada pemodelan UML, diagram ini dapat digunakan untuk menjelaskan proses bisnis dan alur kerja operasional secara langkah demi langkah dari komponen sistem.

Desain User Interface (UI) media pembelajaran di SMP Gunungjati 2 Purwokerto ialah bertujuan untuk merancang sebuah tampilan pada perangkat lunak yang dibuat sebagai halaman antarmuka bagi pengguna. Halaman yang dibuat diharapkan memenuhi kriteria sebagai berikut:

1. Tampilan menarik (disesuaikan dengan user).

2. Fungsi-fungsi yang ada mudah dipahami dan mudah digunakan sehingga memperkecil tingkat kesalahan pada saat pengoperasian (disesuaikan dengan user).

3. Maksud dan isi yang ditampilkan jelas dan mudah dimengerti sesuai dengan tujuan awal pembuatan sistem (disesuaikan dengan user).

\section{Material Collecting (Pengumpulan Bahan Materi)}


Pengumpulan bahan ajar yang akan disajikan dalam media pembelajaran dilakukan pada tahap ini. Bahan-bahan tersebut berupa materi pembelajaran, gambar, animasi, audio, video, dan lain sebagainya untuk menunjang media pembelajaran tersebut.

\section{Assembly (Pembuatan)}

Tahap assembly (pembuatan) adalah tahap pembuatan semua objek atau bahan yang nantinya akan dimasukkan dalam aplikasi pembelajaran. Pembuatan aplikasi didasarkan pada tahap desain. Software yang digunakan dalam tahapan ini adalah Adobe Flash Professional CS6 dengan menggunakan bahasa pemrograman ActionScript. Adapun software pendukung lainnya untuk membuat objek-objek yang nantinya dimasukkan ke dalam media pembelajaran adalah Corel Draw X7 Adobe Photoshop CS6.

\section{Testing (Pengujian)}

Pengujian dilakukan setelah menyelesaikan tahap assembly dengan menjalankan aplikasi dan melihat apakah terdapat error atau kesalahan dalam aplikasi pembelajaran yang dibuat. Tahap yang dilakukan dalam pengujian meliputi pengujian Alpha dan pengujian Beta.

Pengujian Alpha terdiri dari dua tahap, yakni pengujian ahli media dan pengujian ahli materi. Ahli media yang melakukan pengujian terhadap media pembelajaran terdiri dari 1 (satu) orang dosen dari Program Studi Teknik Informatika UMP. Pengujian aplikasi media pembelajaran yang dilakukan oleh ahli media meliputi aspek kemudahan navigasi, integrasi media, artistik dan estetika, serta aspek fungsi keseluruhan karena beberapa aspek tersebut sangat berkaitan dengan fungsionalitas juga interaktifitas media pembelajaran yang dikembangkan. Penilaian aplikasi pembelajaran dilakukan dengan mengacu pada instrumen pengujian kualitas media pembelajaran. Jika terdapat masukkan/saran yang diberikan oleh ahli media, maka masukkan tersebut dianalisis dan digunakan untuk merevisi aplikasi pembelajaran pembelajaran. Setelah proses revisi selesai dan media pembelajaran dikatakan layak oleh ahli media dilakukan pengujian oleh ahli materi.

Ahli materi yang melakukan pengujian terhadap media pembelajaran terdiri dari 1 (satu) orang guru mata pelajaran matematika dari SMP Gunungjati 2 Purwokerto. Pengujian media pembelajaran oleh ahli materi meliputi aspek kandungan kognisi dan penyajian informasi, karena kedua aspek tersebut sangat berkaitan dengan isi materi pada media pembelajaran yang dikembangkan. Pengujian aplikasi media pembelajaran dilakukan dengan mengacu pada instrumen pengujian kualitas media pembelajaran. Jika terdapat masukkan/saran yang diberikan oleh ahli materi, maka masukkan tersebut dianalisis dan digunakan untuk merevisi materi pembelajaran. Setelah proses revisi selesai dan media pembelajaran dikatakan layak oleh ahli materi dilakukan pengujian Beta.

Pengujian Beta dilakukan oleh siswa kelas VII di SMP Gunungjati 2 Purwokerto. Pengujian aplikasi pembelajaran oleh siswa meliputi aspek kemudahan navigasi, penyajian informasi, integrasi media, artistik dan estetika, serta aspek fungsi keseluruhan. Jika terdapat masukkan/saran, maka masukkan tersebut dianalisis dan digunakan untuk merevisi media pembelajaran. Setelah proses revisi selesai dilakukan tahap distribusi.

\section{Distribution (Pendistribusian)}

Aplikasi media pembelajaran yang telah melalui tahap pengujian akan disimpan dalam media penyimpanan berupa Compact Disk (CD). Setelah dilakukan penyimpanan, aplikasi pembelajaran didistribusikan ke guru mata pelajaran matematika untuk dijadikan sebagai alat bantu mengajar dalam proses pembelajaran.

\section{HASIL DAN PEMBAHASAN}


Hasil akhir yang diperoleh dari pengembangan ini adalah sebuah aplikasi pembelajaran matematika yang dikemas dalam bentuk compact disk (CD). Aplikasi pembelajaran ini digunakan untuk membantu siswa kelas VII dalam mempelajari materi segitiga dan segiempat. Pada tahapan pengembangan aplikasi pembelajaran digunakan metode MDLC yang terdiri dari 6 tahapan dan akan dijelaskan sebagai berikut:

\section{Concept (Konsep)}

Tahap konsep merupakan tahap untuk menentukan tujuan, jenis, konsep media, materi pembelajaran, kegunaan, dan sasaran pengguna dari pembuatan aplikasi multimedia. Secara umum proses yang dilakukan pada tahap konsep adalah menentukan tujuan media pembelajaran, menentukan konsep isi media pembelajaran, dan menentukan konsep materi pembelajaran.

Aplikasi pembelajaran matematika ditujukan untuk siswa kelas VII di SMP Gunungjati 2 Purwokerto. Aplikasi pembelajaran ini bertujuan untuk membantu proses pembelajaran, diharapkan dapat meningkatkan motivasi belajar siswa pada mata pelajaran matematika pokok bahasan segiempat dan segitiga, serta meningkatkan potensi nilai siswa. Isi materi pembelajaran mengacu pada silabus Kurikulum 2013 yang digunakan di SMP Gunungjati 2 Purwokerto. Materi pembelajaran yang diambil adalah menjelaskan jenis, sifat, serta menurunkan rumus keliling juga rumus luas pada segiempat dan segitiga. Konsep penyajian materi yang akan ditampilkan pada media pembelajaran meliputi penjelasan materi berupa teks, gambar, dan video. Selain memuat pateri pembelajaran, media pembelajaran matematika juga di dalamnya memuat standar kompetensi atau kompetensi dasar, video pembahasan soal, dan kuis.

\section{Design (Desain)}

Hasil perancangan Use Case Diagram media pembelajaran matematika kelas VII SMP Gunungjati 2 Purwokerto ditunjukkan pada Gambar 2. Use Case Diagram merepresentasikan hubungan antara pengguna dengan aplikasi media pembelajaran. Materi pada media pembelajaran terbagi menjadi 4 Submenu, yaitu Submenu Segiempat, Segitiga, Penerapan, juga Keliling dan Luas. Salah satu activity diagram materi adalah materi Submenu Segitiga (Gambar 3). Pada activity diagram Submenu Segitiga menjelaskan tentang proses menampilkan dan menjalankan menu materi tersebut. Pada proses ini guru terlebih dahulu membuka aplikasi media pembelajaran, lalu tekan tombol menu materi. Pada halaman ini akan menampilkan empat submenu materi dan tombol kembali ke menu utama yang berfungsi untuk kembali ke halaman utama, lalu pilih submenu segitiga. Pada materi ini, terdapat empat halaman dan setiap halaman berisi penjelasan tentang materi segitiga. Di dalam halaman 1 (satu) terdapat tombol next yang berfungsi mengarahkan ke halaman berikutnya. Ketika ditekan ke halaman 2 (dua), maka akan menampilkan isi materi yang berbeda dari halaman 1 (satu). Di dalam halaman kedua dan ketiga terdapat dua tombol yaitu next dan previous. Tombol next berfungsi untuk melanjutkan ke halaman berikutnya, sedangkan tombol previous akan mengarahkan ke halaman sebelumnya. Di halaman 4 (empat)/terakhir hanya terdapat satu tombol, yaitu previous. Tombol previous akan mengarahkan ke halaman sebelumnya. Terdapat tombol kembali ke menu materi di sebelah kiri aplikasi pada setiap halaman yang berfungsi untuk kembali halaman menu materi. 


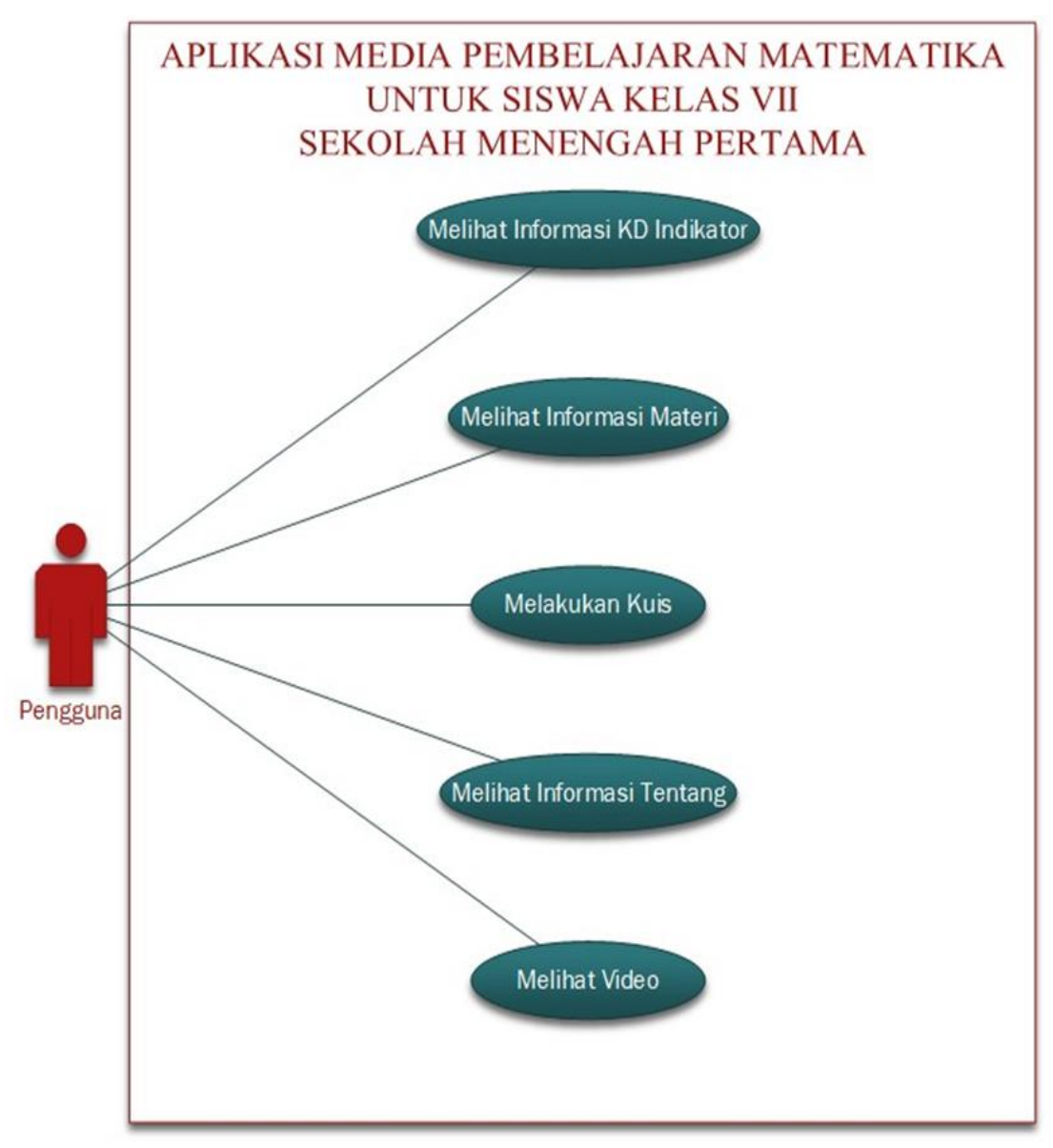

Gambar 2. Use Case Diagram Aplikasi Media Pembelajaran Matematika

Perancangan user interface aplikasi ini menampilkan gambar berupa desain antar muka untuk mengetahui isi Aplikasi Pembelajaran Matematika untuk Kelas VII Sekolah Menengah Pertama. Berikut merupakan beberapa hasil perancangan antar muka yang yakni Halaman Menu Materi (Gambar 4) dan Halaman Materi Segitiga (Gambar 5). Desain halaman menu materi berisi empat sub materi yang dapat disampaikan oleh guru dalam proses pembelajaran di dalam kelas. Di dalam halaman ini terdapat submenu segiempat, segitiga, penerapan, keliling dan luas, serta tombol ke menu utama yang berfungsi untuk kembali ke halaman utama. Desain submenu materi segitiga berisi materi yang dapat disampaikan oleh guru dalam proses pembelajaran di dalam kelas. Di dalam halaman ini terdapat tombol ke menu materi untuk kembali ke halaman materi, tombol next untuk melanjutkan ke halaman selanjutnya, tombol previous untuk kembali ke halaman sebelumnya. 
SAINTEKS

Volume 16 No 1, April 2019

ISSN: 0852-1468 (43-53)

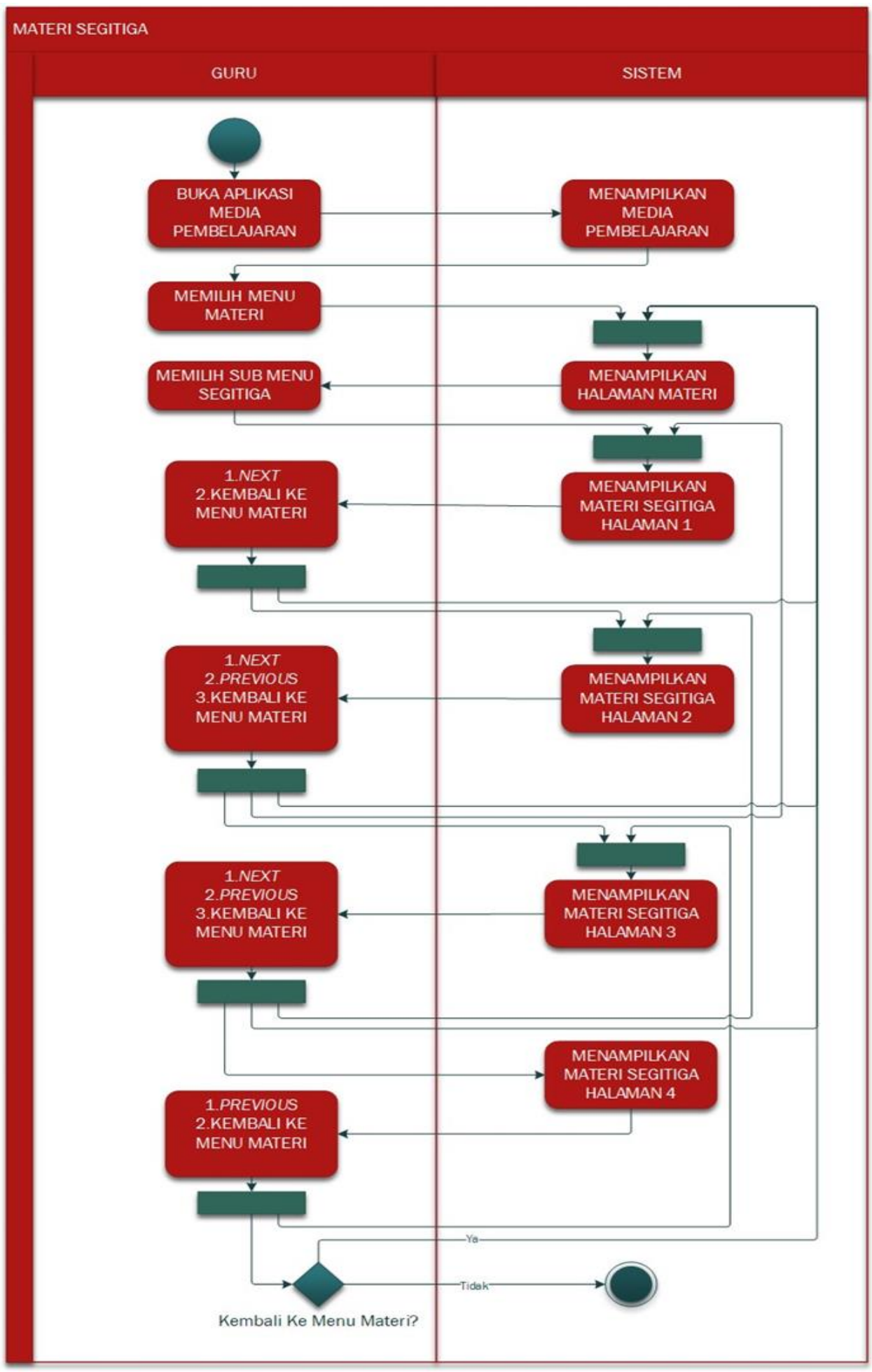

Gambar 3. Activity Diagram Materi Submenu Segitiga 


\section{JUDUL APLIKASI}

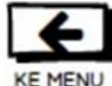

KE MENU

UTAMA

\section{JUDUL MENU}
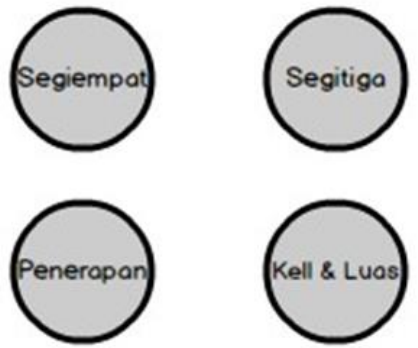

Gambar 4. Desain Halaman Menu Materi

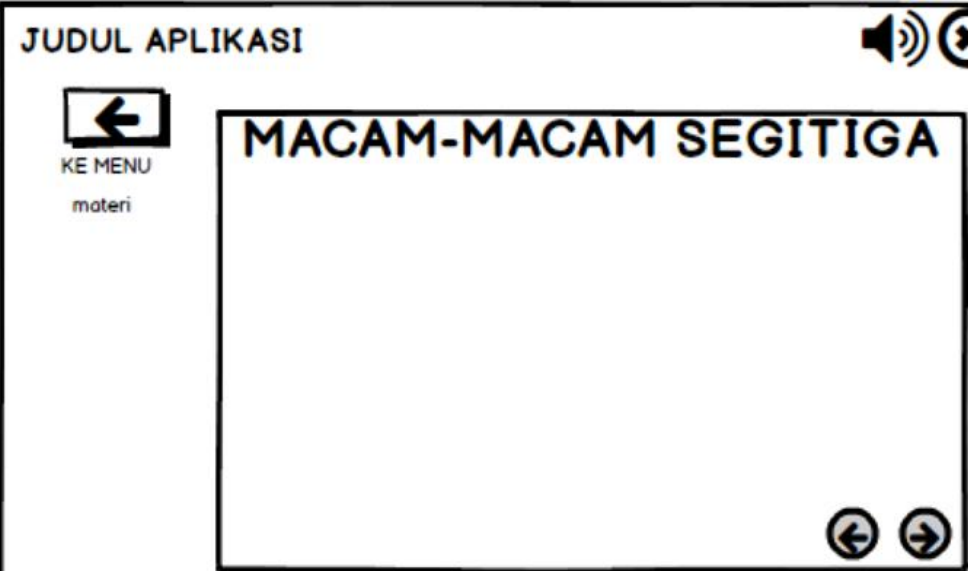

Gambar 5. Desain Halaman Materi Segitiga

\section{Material Collection (Pengumpulan Bahan Materi)}

Pengumpulan bahan yang sesuai dengan kebutuhan dilakukan pada tahap ini. Hasil yang didapatkan pada tahan pengumpulan bahan adalah sebagai berikut:

1. Bahan-bahan materi pelajaran Matematika kelas VII berdasarkan Kurikulum 2013.

2. Gambar penunjang yang berfungsi sebagai objek animasi pada aplikasi pembelajaran dan penjelas pada bagian materi.

3. Audio yang berfungsi sebagai musik latar pada aplikasi pembelajaran.

4. Video pembahasan yang berhubungan dengan materi.

5. Soal pilihan ganda.

\section{Assembly (Pembuatan)}

Pembuatan media pembelajaran yang sesuai dengan desain yang telah dibuat sebelumnya dilakukan pada tahap ini. Secara garis besar aplikasi pembelajaran ini terdiri dari kompetensi dasar, materi, tentang, video, dan kuis.

Pembuatan aplikasi pembelajaran ini dimulai dengan mendesain tampilan demi tampilan di Adobe Flash CS6. Setelah semua desain selesai dibuat, selanjutnya diberikan 
action script 2.0 agar aplikasi pembelajaran dapat berjalan sesuai dengan yang diharapkan dan dapat menunjang fungsionalitas serta interaktifitas. Adapun hasil pembuatan aplikasi pembelajaran matematika adalah sebagai berikut.

\section{Tampilan Halaman Menu Utama}

Halaman menu utama aplikasi pembelajaran berisikan tombol-tombol. Pada bagian pojok kanan atas terdapat tombol keluar untuk menutup atau keluar dari aplikasi, tombol musik untuk mengaktifkan musik dan mematikan musik. Pada bagian pojok kiri tercantum judul aplikasi pembelajaran. Pada bagian tengah terdapat tombol menu utama aplikasi pembelajaran, yaitu tombol KD Indikator, tombol Materi, tombol Quiz, tombol Tentang, dan tombol Video. Tampilan halaman utama aplikasi pembelajaran dapat dilihat pada Gambar 6.

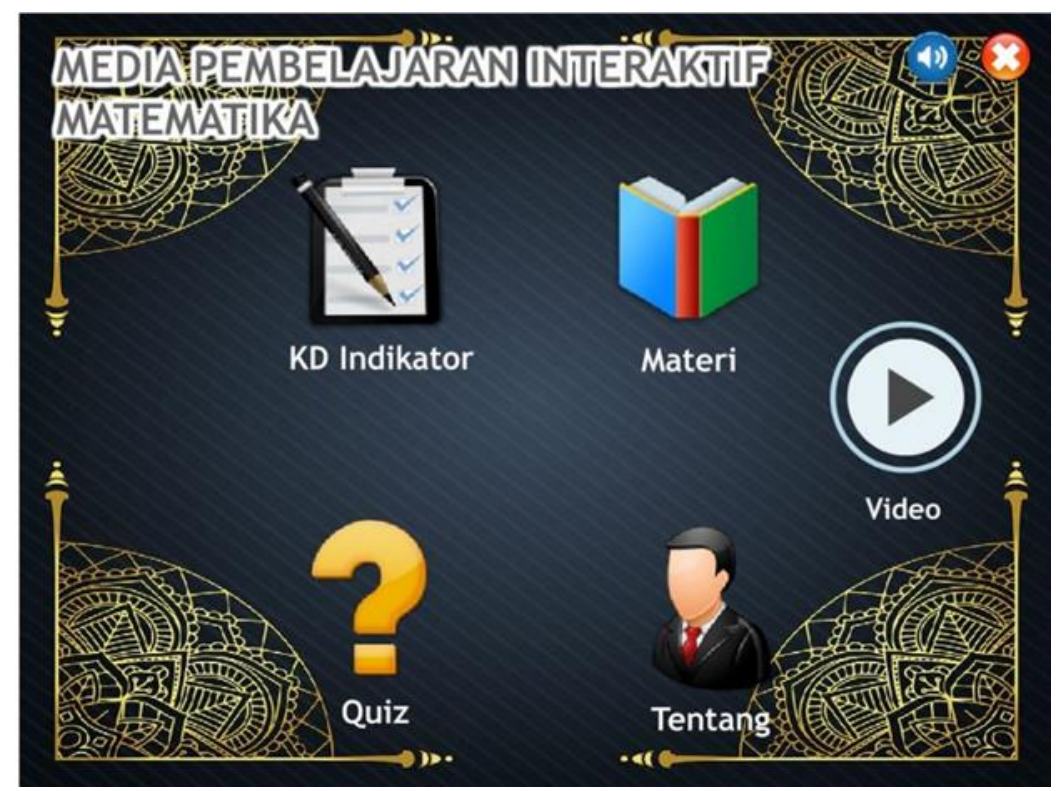

Gambar 6. Tampilan Halaman Menu Utama

\section{Tampilan Halaman Materi}

Halaman materi berisi tombol submenu materi yang terdiri dari empat pokok materi yaitu: segiempat, segitiga, penerapan, keliling dan luas. Keempat tombol tersebut jelas memiliki fungsi yang berbeda-beda, diantaranya (1) submenu segiempat untuk menuju ke halaman isi materi yang menjelaskan pengertian, jenisjenis dan sifatsifat segiempat, (2) submenu segitiga untuk menuju ke halaman isi materi yang menjelaskan pengertian, jenisjenis dan sifat-sifat segitga, (3) submenu penerapan untuk menuju ke halaman isi materi yang mencontohkan bentuk segiempat dan segitga di kehidupan nyata, (4) submenu keliling dan luas untuk menuju ke halaman isi materi tentang rumus keliling serta luas dari segiempat juga segitiga. Dalam submenu ini memiliki tombol untuk mengakses tombol hitung yang dapat digunakan untuk simulasi perhitungan keliling dan luas. Tampilan halaman materi dapat dilihat pada Gambar 7, tampilan halaman submenu materi segiempat dapat dilihat ada Gambar 8, halaman submenu materi segitiga dapat dilihat pada Gambar 9. 


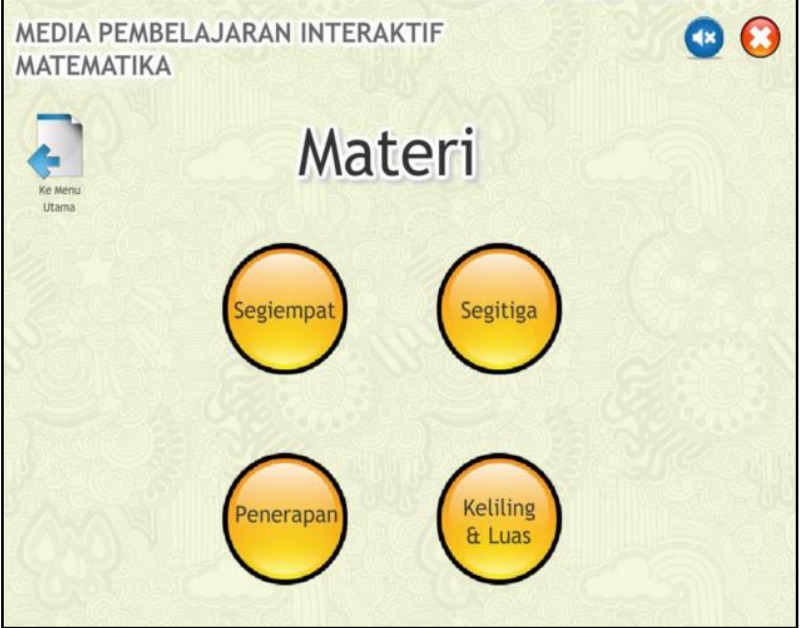

Gambar 7. Tampilan Halaman Materi.

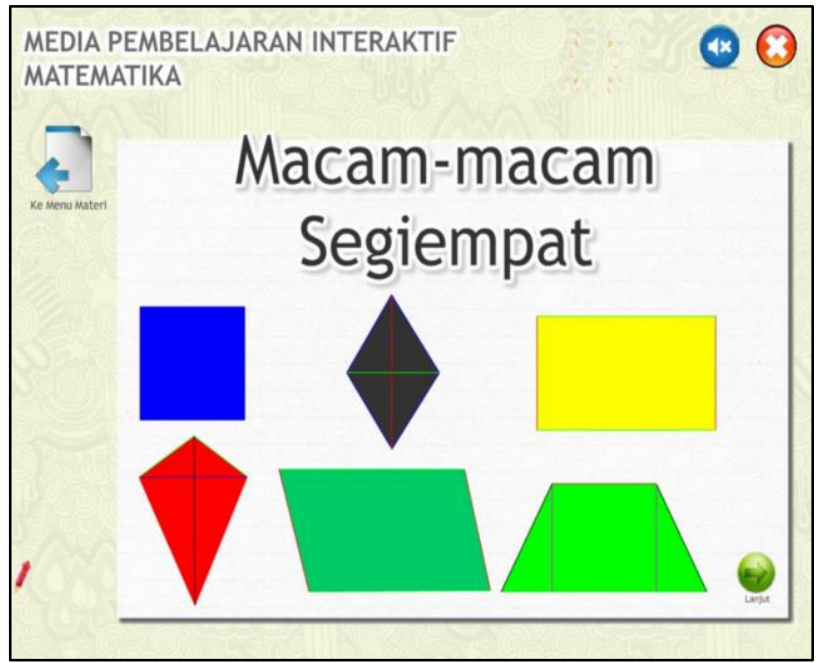

Gambar 8. Tampilan Halaman Submenu Materi Segiempat

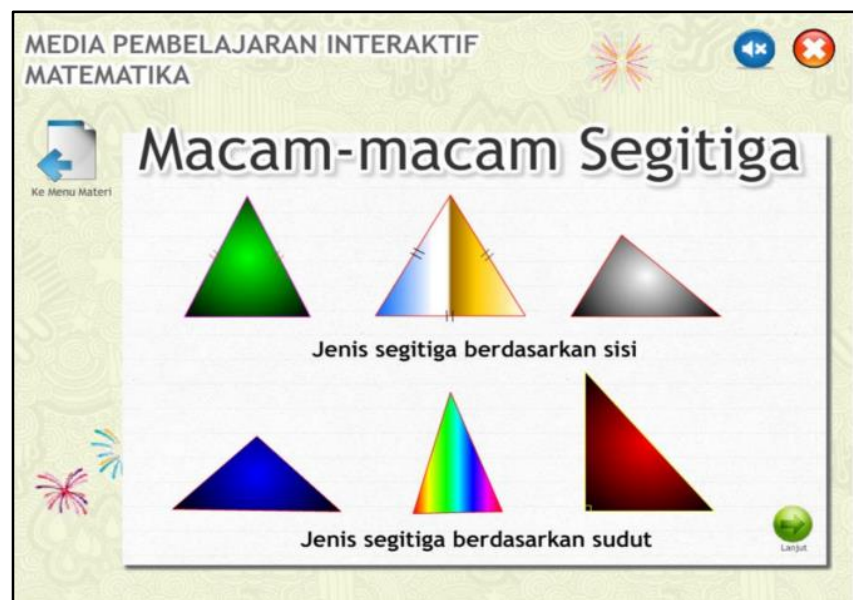

Gambar 9. Tampilan Halaman Submenu Materi Segitiga 


\section{Testing (Pengujian)}

Hasil pengujian alpha yang dilakukan oleh ahli media/aplikasi pembelajaran masuk katergori baik. Hasil ini ditunjukkan oleh angket pengujian yang telah diisi oleh ahli materi. Komentar dan saran yang diberikan oleh ahli media dijadikan sebagai dasar untuk merevisi media pembelajaran matematika yang dikembangkan. Adapun komentar dan saran yang diberikan oleh ahli media di antaranya (1) Bagian beranda diisi dengan pengantar media animasi, dan (2) Beberapa kesalahan pengetikkan harus diperbaiki. Sedangkan hasil pengujian alpha yang dilakukan oleh ahli materi juga masuk dalam katergori baik. Hasil ini didapatkan dari angket pengujian yang telah diisi oleh ahli materi. Komentar dan saran oleh ahli materi dijadikan sebagai dasar untuk merevisi media pembelajaran matematika yang dikembangkan. Adapun komentar dan saran yang diberikan oleh ahli materi di antaranya (1) Tulisan diperbesar dan diperjelas (2) Lengkapi materi dengan gambar, dan (3) Materi soal perlu ditambah.

Pengujian Beta dilakukan oleh siswa kelas VII di SMP Gunungjati 2 Purwokerto. Pengujian ini bertujuan untuk mengevaluasi reaksi siswa terhadap media pembelajaran dan untuk mengetahui seberapa besar tingkat kelayakan media pembelajaran matematika. Hasil pengujian yang dilakukan oleh siswa masuk dalam kategori Baik yang ditunjukkan oleh hasil angket yang diisi oleh siswa kelas VII SMP Gunungjati 2 Purwokerto.

\section{Distribution (Pendistribusian)}

Proses yang dilakukan dalam tahap ini adalah menyimpan media pembelajaran ke media penyimpanan yang berupa Compact Disk (CD). Setelah dilakukan penyimpanan, media pembelajaran didistribusikan ke guru mata pelajaran matematika untuk dijadikan sebagai alat bantu mengajar dalam proses pembelajaran.

\section{KESIMPULAN}

Penelitian ini telah menghasilkan aplikasi media pembelajaran Matematika pada Materi Segi Tiga dan Segi Empat dengan menggunakan metode Multimedia Development Life Cycle (MDLC). Berdasarkan hasil pengujian (alpha \& beta testing), aplikasi media pembelajaran ini layak digunakan untuk membantu proses belajar mengajar di kelas. Selain itu, berdasarkan angket yang diisi oleh responden (guru dan siswa), aplikasi media pembelajaran ini juga dapat membantu guru dalam menyampaikan materi di kelas, meningkatkan motivasi belajar siswa, dan meningkatkan prestasi siswa.

\section{DAFTAR PUSTAKA}

Daryanto. (2013). Media Pembelajaran Perannya Sangat Penting Dalam Mencapai Tujuan Pembelajaran. Gava Media. Yogyakarta.

Juriah. (2014). Penggunaan Multimedia dalam Meningkatkan Motivasi Belajar Siswa Pada Mata Pelajaran Aqidah Kelas X TKJ SMK Muhammadiyah 3 SurakartaTahun Pelajaran 2013/2014. Skripsi. Fakultas Agama Islam. Universitas Muhammadiyah Surakarta. Surakarta.

Setiawan, H. (2013). Peran Multimedia Dalam Meningkatkan Motivasi Belajar Siswa Kelas XI IS SMA Al-Islam 3 Surakarta Tahun Pelajaran 2012/2013. Skripsi. Fakultas Agama Islam. Universitas Muhammadiyah Surakarta. Surakarta.

Suhardi, Idwan, dkk. (2013). Penguasaan, Pemanfaatan dan Pemajuan Teknologi Informasi dan Komunikasi (TIK) Guna Kejayaan Bangsa dalam Rangka Ketahanan Nasional. Jurnal Kajian Lemhannas RI, 16(2). 42-55.

Sutopo. (2003). Multimedia Interaktif dengan Flash. Graha Ilmu.Yogyakarta. 